\title{
Development and propagation of a pollution gradient in the marine boundary layer during INDOEX (1999)
}

\author{
Matthew Simpson and Sethu Raman* \\ Department of Marine, Earth, and Atmospheric Sciences, North Carolina State University, Raleigh, \\ NC 27695-8208, USA. \\ *e-mail: sraman@ncsu.edu
}

\begin{abstract}
The development and propagation of a pollution gradient in the marine boundary layer over the Arabian Sea during the Intensive Field Phase of the Indian Ocean Experiment (1999) is investigated. A hypothesis for the generation of the pollution gradient is presented. Infrared satellite images show the formation of the pollution gradient as the leading edge of a polluted air mass in the marine boundary layer and also its propagation over the Arabian Sea and the northern Indian Ocean. Aerosol data measured from two research vessels over the Arabian Sea show a variation in the concentrations caused by the passage of this pollution gradient. Depth of the pollution gradient was found to be about $800 \mathrm{~m}$. A numerical model was used to simulate the development of this gradient and its propagation over the ocean. Results show that its formation and structure are significantly influenced by the diurnal cycle of coastal sea-land breeze circulations along India's west coast. Transport of aerosols and gases over the Arabian Sea in the lower troposphere from land sources appears to be through this mechanism with the other being the elevated land plume.
\end{abstract}

\section{Introduction}

The Intensive Field Phase (IFP) of the Indian Ocean Experiment (INDOEX) was carried out over the tropical Indian Ocean from 14th January to 31st March 1999. The goal of INDOEX is to improve our understanding of the possible effect of anthropogenic aerosols and gases on the global radiation balance (Ramanathan et al 1995). Latitudinal gradients in aerosol concentrations were observed over the tropical Indian Ocean by ship-borne measurements prior to INDOEX (1999) (Satheesh et al 1998). The Research Vessel (R/V) Ron Brown measured aerosol concentrations during INDOEX (1999) over the tropical Indian Ocean and the Arabian Sea. As in the previous years, strong gradients in aerosol concentrations were observed and the concentrations changed with latitude over the Arabian Sea.

Latitudinal gradients in anthropogenic gases have been observed over the Arabian Sea and the Indian Ocean. Higher marine boundary layer ozone concentrations were observed over the Indian Ocean in the northern hemisphere during the northeast monsoon season (Johnson et al 1990). Direct transport of anthropogenic emissions resulting in sharp increases in $\mathrm{CO}, \mathrm{CO}_{2}, \mathrm{O}_{3}$, and $\mathrm{NO}_{\mathrm{y}}$ have been detected at distances of $1500 \mathrm{~km}$ from southern India (Rhoads et al 1997). Sudden increases in $\mathrm{O}_{3}, \mathrm{CO}$, and aerosol mass concentrations of sizes less than $0.6 \mu \mathrm{m}$ have been observed with back trajectories showing air mass transport from the Indian subcontinent (Lal et al 1998).

Enhanced aerosol optical depths have also been observed over the Arabian Sea. Regions of high aerosol optical depths were observed over the ocean along the west coast of India around $10^{\circ} \mathrm{N}$ and over the western Arabian Sea (Moorthy and Saha 2000). Moorthy and Saha (2000) suggest that the high aerosol optical depths over the eastern Arabian Sea are a result of transport from sources along the west coast of India.

Keywords. INDOEX; pollution gradient; marine boundary layer; northeast monsoon. 


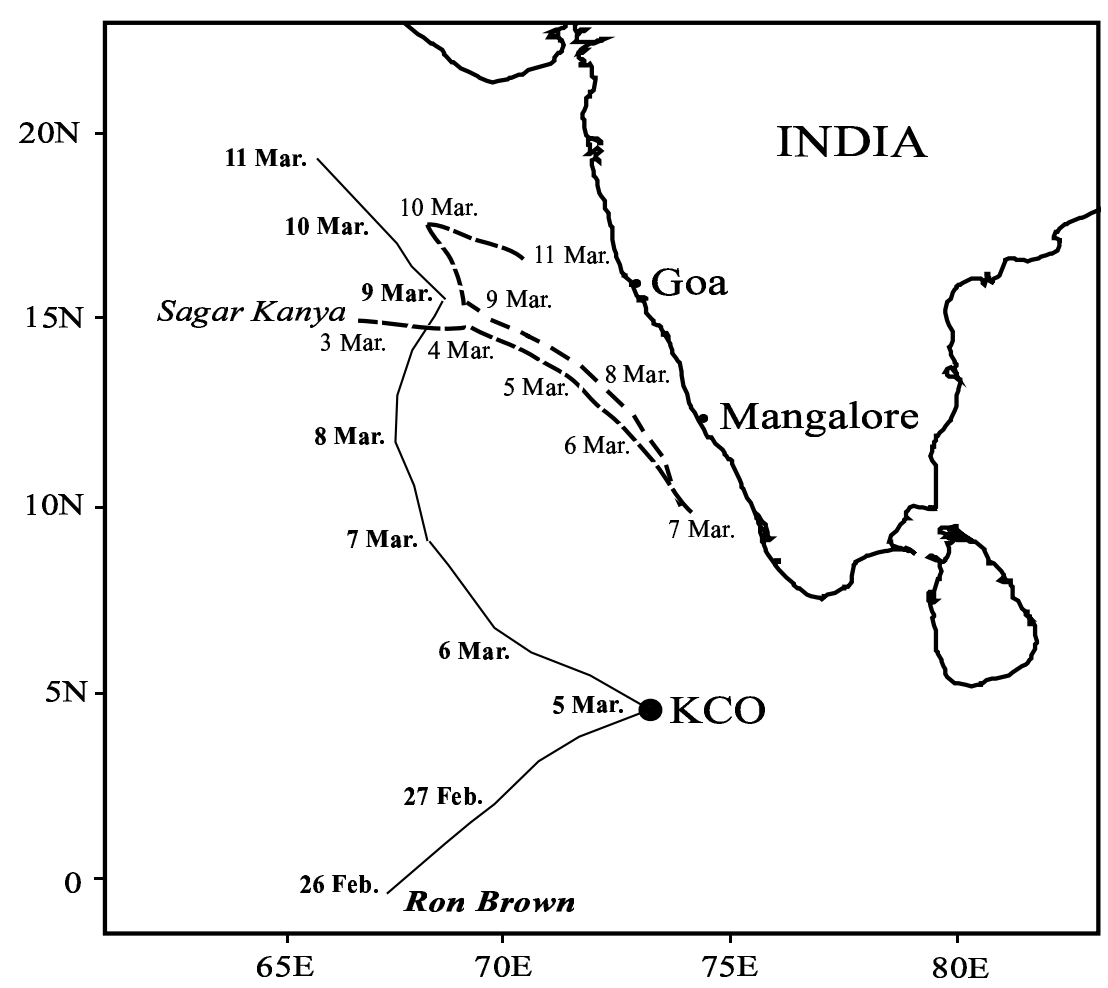

Figure 1. Ship tracks of research vessels Ron Brown and Sagar Kanya during the parallel track experiment phase of INDOEX during March 1999. Location is represented by day of March.

Westward propagating cloud bands were observed using a geo-stationary satellite during INDOEX (1999) (Désalmand et al 2003). Infrared temperatures recorded by the Meteosat- 5 satellite showed cloud tops to be about $5^{\circ} \mathrm{C}$ colder than the sea surface temperature over the Arabian Sea, which corresponds to a cloud height of 600 to $1000 \mathrm{~m}$. In all, sixteen transient cloud bands were observed in satellite imagery from 1st January to 15th April 1999 with the most frequent observations occurring in early March.

Marine boundary layer dynamics were studied far less than aerosol forcing and concentrations during INDOEX. As a result, the role of the marine boundary layer in pollution transport over the Arabian Sea is not well understood. In this paper, we present observations and numerical modeling results to show that the observed cloud bands during INDOEX were in fact pollution gradients occurring in the marine boundary layer. These pollution gradients are described as leading edges of a polluted air mass from the Indian subcontinent with relatively high aerosol and anthropogenic gas concentrations. Infrared satellite data are used to show the development of this pollution gradient along the west coast of India and its propagation over the Arabian Sea. A hypothesis is presented for the development and propagation of this pollution gradient and tested using a high-resolution mesoscale numerical model.
Results from this numerical simulation are compared with observations to achieve a better understanding of the characteristics of the pollution gradient.

\section{Observations}

Several different data platforms were used during INDOEX (1999) that measured data relevant to the formation and propagation of the pollution gradient. These platforms include R/Vs Ron Brown and Sagar Kanya, the Meteosat-5 infrared satellite, and coastal soundings from Mangalore, India $\left(12.9^{\circ} \mathrm{N} ; 74.9^{\circ} \mathrm{E}\right)$. Detailed descriptions of the various platforms are presented below.

$\mathrm{R} / \mathrm{V}$ Ron Brown was equipped with instrumentation to measure aerosol concentrations and various anthropogenic pollutants during INDOEX (1999). Aerosol data used in this paper were measured from R/V Ron Brown from the equator to $20^{\circ} \mathrm{N}$ over the northern Indian Ocean and the Arabian Sea. The R/V Ron Brown aerosol concentration data used in this paper were obtained from the INDOEX (1999) database maintained by Joss Data Management called CODIAC that supplies public domain data from INDOEX to researchers.

The tracks of R/Vs Ron Brown and Sagar Kanya during the parallel track portion of INDOEX (1999) are shown in figure 1. R/V Ron Brown's 
track is from 4th March to 11th March 1999. R/V Ron Brown was approximately $800 \mathrm{~km}$ off the west coast of India and recorded high concentrations of aerosols and carbon monoxide over the Arabian Sea at this distance offshore. Measured concentrations of the aerosols and $\mathrm{CO}$ showed a variation based on the propagation of pollution gradients over the Arabian Sea. R/V Sagar Kanya's track shown in figure 1 is from 3rd March to 11th March 1999 while the ship came within $140 \mathrm{~km}$ of the west coast of India. This parallel track was designed so that the two ships could record the development of the marine boundary layer (MBL) and the offshore variation in anthropogenic aerosols and gases.

Meteosat-5 is a meteorological satellite with a geo-stationary orbit operating within the worldwide network of the World Weather Watch of the World Meteorological Organization (WMO). The general mission of Meteosat-5 was imaging in the visible, infrared, and water vapor region of the spectrum.

Mangalore $\left(12.9^{\circ} \mathrm{N} ; 74.9^{\circ} \mathrm{E}\right)$ is located along India's west coast as shown in figure 1. Pilot balloon soundings were made twice a day at $0500 \mathrm{LT}$ and 1700 LT at Mangalore during INDOEX (1999). Soundings from Mangalore are used to show the development of the land and sea breeze along the west coast of India.

\section{Pollution gradient}

We define the pollution gradient observed over the Arabian Sea as a boundary between one air mass high in aerosol and anthropogenic gas concentrations originating from the Indian subcontinent and another unpolluted marine air mass located to the southwest over the Arabian Sea. A sharp gradient in aerosol concentrations and other pollutants in the marine boundary layer occurs at the leading edge of the polluted continental air mass. This region of high concentrations represents the boundary between the unpolluted marine air mass over the Arabian Sea and the polluted air mass from the Indian subcontinent. Formation of the pollution gradient occurs when offshore winds caused by the nighttime land breeze and the northeast monsoon winds aloft transport the polluted continental air mass over the Arabian Sea. Location of the pollution gradient is defined as where the transported polluted continental air mass meets the less polluted marine air mass. Observations of the pollution gradient over the Arabian Sea are presented below to more thoroughly describe the phenomenon.

A hypothesis to describe the development and propagation of the pollution gradient in the marine boundary layer is shown in figure 2 . The presented
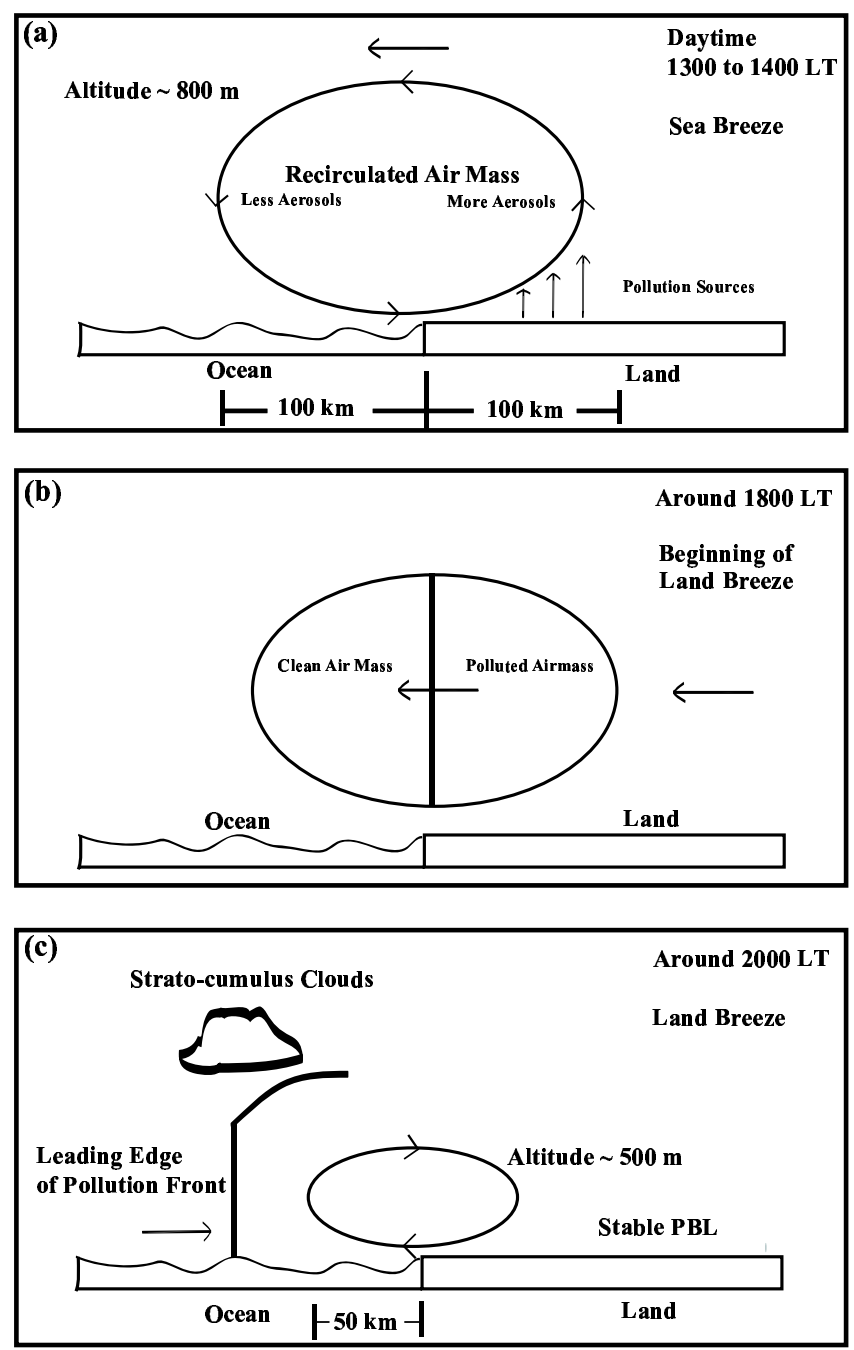

Figure 2. (a) Schematic diagram showing the development of the coastal sea breeze circulation along the west coast of India, (b) development of the pollution gradient as the nighttime land breeze strengthens, (c) and the transport of the pollution gradient over the Arabian Sea by the land breeze.

hypothesis involves the onshore sea breeze and the offshore land breeze circulations. With the occurrence of the sea breeze circulation in the daytime, a progressively polluted air mass develops particularly over the land portion of the circulation. Strong convergence along the sea breeze front over land would also have a high concentration of pollutants when there is no deep convection and associated precipitation. By around $1400 \mathrm{LT}$, the sea breeze circulation is well developed and a marine air mass with low aerosol concentrations is transported onshore as depicted schematically in figure 2(a). A sea breeze front then forms inland as discussed above with the observations from Mangalore, India. Around $1800 \mathrm{LT}$, the sea breeze circulation begins to weaken and the prevailing winds shift to northeasterly as illustrated in figure 2(b). As the nighttime land breeze intensifies, 
the polluted air mass is transported out to sea by the land breeze and is in the same direction as the synoptic wind (easterly). By about 2200 LT, a pollution gradient forms offshore as the leading edge of this polluted air mass in the marine boundary layer. Strong high-pressure system to the north of India's west coast can enhance the offshore flow during the night. Katabatic flow down the mountains located about $100 \mathrm{~km}$ inland can also increase the offshore flow. Low-level convergence appears to result as the polluted air mass encounters relatively pristine marine air mass as illustrated in figure 2(c). Weak positive vertical velocities occur at this convergence zone associated with the pollution gradient and result in the formation of the observed low level stratocumulus clouds.

Aerosol concentrations measured aboard $\mathrm{R} / \mathrm{V}$ Ron Brown, located $800 \mathrm{~km}$ off the west coast of India, are analyzed to investigate the presence of the pollution gradient. Specifically, peaks in the aerosol concentrations should be present as the gradient moves past $\mathrm{R} / \mathrm{V}$ Ron Brown. The aerosol concentration distributions measured by R/V Ron Brown are 30-minute averages in 24 size bins with aerodynamic diameters ranging from 0.9 to 4.7 micrometers. Aerosol concentrations were measured at $18 \mathrm{~m}$ above sea level through a heated mast. Densities used to convert the diameters were calculated using a thermodynamic equilibrium model (AeRho). AeRho uses ion chromatograph data from impactor measurements and the measured $\mathrm{RH}$ to determine the densities for each impactor stage (Quinn and Coffman 1998). These calculations assume the aerosol to be internally mixed. The result is a density distribution for each impactor-sampling period.

An analysis of aerosol data from R/V Ron Brown located at about $800 \mathrm{~km}$ off the west coast of India during the parallel track experiment of INDOEX (1999) reveals a variation in aerosol concentration. Latitudinal variation in aerosol number size distributions for radius $0.072-0.084 \mu \mathrm{m}$ measured from R/V Ron Brown during INDOEX (1999) is shown in figure 3 (solid line). The data were measured from 4th March to 10th March 1999 with the latitudes ranging from $5^{\circ} \mathrm{N}$ to $18^{\circ} \mathrm{N}$. Several noticeable peaks in aerosol concentrations are seen in the data caused by the successive pollution gradients. The first peak (labeled A) occurred on 5th March at 0100 LT with a concentration of 1700 particles $\mathrm{cm}^{-3}$ at $5^{\circ} \mathrm{N}$. The aerosol distribution quickly falls to 800 particles $\mathrm{cm}^{-3}$ after the peak. Another peak (B) is seen two days later on 7th March 0100LT with a concentration of 1200 particles $\mathrm{cm}^{-3}$ at $8^{\circ} \mathrm{N}$. However, this increase in aerosols measured from $\mathrm{R} / \mathrm{V}$ Ron Brown resulting in the peak at $0100 \mathrm{LT}$ on 7 th March begins around 1300 LT on 6th March. This

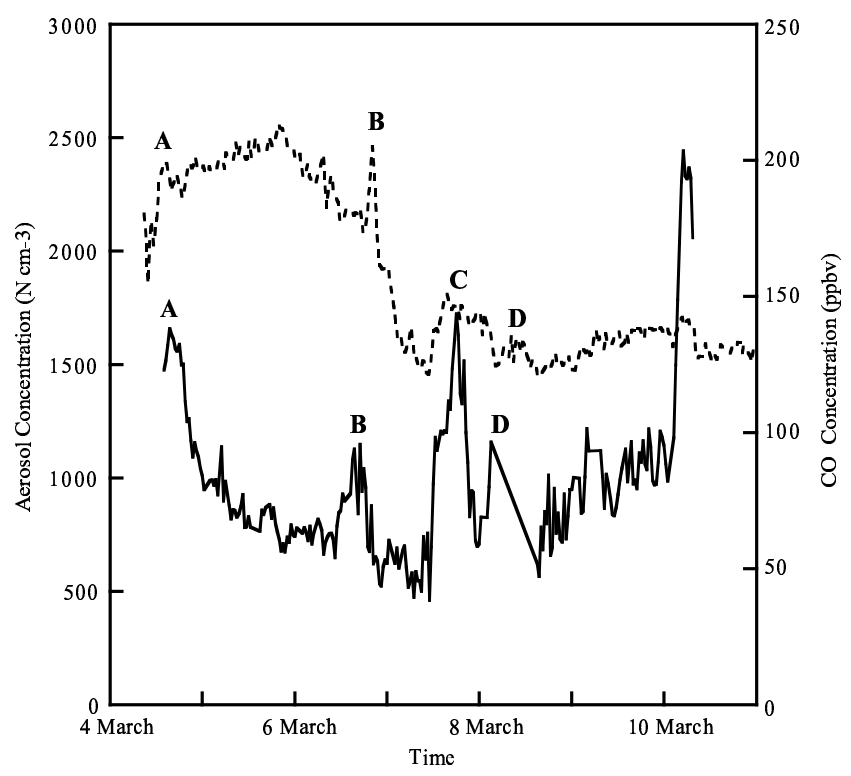

Figure 3. Aerosol number concentrations and carbon monoxide concentration measured from R/V Ron Brown from 4th March to 11th March 1999 during the parallel track experiment showing peaks in concentration caused by the propagation of pollution gradients over the Arabian Sea.

time corresponds to a pollution gradient passage observed in satellite imagery that will be shown later in figure 6(d). After the peak, the aerosol concentration again falls to 800 particles $\mathrm{cm}^{-3}$. Another strong peak (C) in aerosol concentration is seen 19 hours later on 7th March 2000 LT at $12^{\circ} \mathrm{N}$. Again the aerosol concentration falls to around 800 particles $\mathrm{cm}^{-3}$ after a sharp increase. Another peak (D) in the aerosol concentration is seen on 8th March at $1500 \mathrm{LT}$ at $14^{\circ} \mathrm{N}$. The magnitude of this aerosol concentration peak is 1200 particles $\mathrm{cm}^{-3}$.

Carbon monoxide measurements from $\mathrm{R} / \mathrm{V}$ Ron Brown also show the presence of a pollution gradient. Latitudinal variations in carbon monoxide concentration at a height of $18 \mathrm{~m}$ measured from $\mathrm{R} / \mathrm{V}$ Ron Brown are shown in figure 3 (dashed line). A TECO $48 \mathrm{CO}$ instrument was used to collect the $\mathrm{CO}$ data and a thorough description is given by Stehr et al (2002). The CO data were then averaged into 30-minute time bins. Peaks in carbon monoxide measured from $\mathrm{R} / \mathrm{V}$ Ron Brown can be correlated with the times of peaks in the aerosol concentrations. The first peak (A) in CO concentration was observed on 5th March 0100 LT at $5^{\circ} \mathrm{N}$ with a concentration of $195 \mathrm{ppb}$. Concentrations gradually decrease until the pollution gradient passage shown in figure $6(\mathrm{~d})$ results in a peak (B) of $210 \mathrm{ppb}$ on 7th March at 0100 LT at $8^{\circ} \mathrm{N}$. Again the concentration gradually decreases and the next peak (C) is seen at $12^{\circ} \mathrm{N}$ on 7 th March 2000 LT with a concentration of $150 \mathrm{ppb}$. 


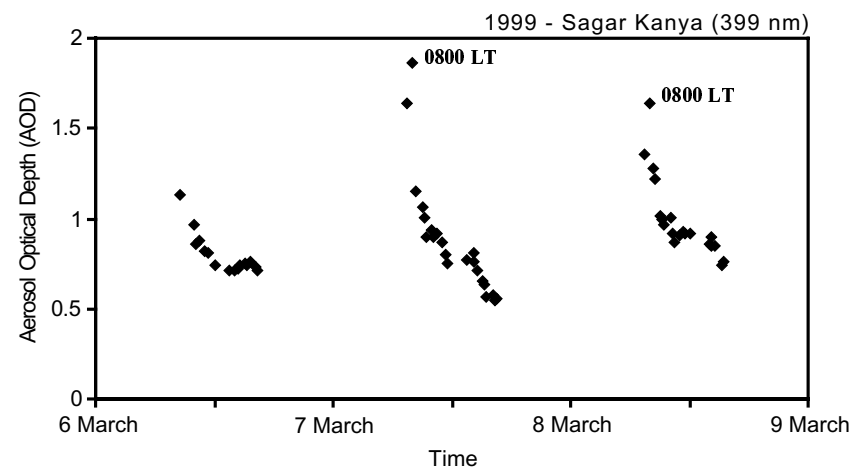

Figure 4. Aerosol optical depths measured from research vessel Sagar Kanya during the parallel track experiment showing peaks in AOD at 0800 LT on 7th March and 0800 LT on 8th March resulting from the passage of pollution gradients over the Arabian Sea.

As with the aerosol data, a small peak in the $\mathrm{CO}$ concentration is seen on 8th March $1500 \mathrm{LT}$ at $14^{\circ} \mathrm{N}$ with a concentration of $135 \mathrm{ppb}$. Unlike the aerosol concentration data, the carbon monoxide concentration did not increase significantly with latitude over the Arabian Sea possibly because of the different removal mechanism and residence time. However, the presence of identical times of occurrence of carbon monoxide and aerosol concentration peaks showed the presence of the pollution gradient where all pollutants are expected to increase sharply.

R/V Sagar Kanya came to within $140 \mathrm{~km}$ of the west coast of India during the parallel track experiment portion of INDOEX (1999). The location of the R/V Sagar Kanya provides an excellent opportunity to observe the transport of aerosols from the Indian subcontinent over the Arabian Sea. Aerosol optical depth (AOD) was measured from a sun-photometer aboard R/V Sagar Kanya during INDOEX 1999 (Jayaraman et al 2001). AOD observations made during daytime hours from 6th March to 9th March 1999 are shown in figure 4. High AOD values of 1.6 to 1.8 optical depth units were observed at $0800 \mathrm{LT}$ on 7 th March and at 0800 LT on 8th March respectively. These high AOD values in the morning hours result from the transport of the pollution gradients over the Arabian Sea by the nighttime land breeze. Since R/V Sagar Kanya is $140 \mathrm{~km}$ off the west coast of India, it will take the pollution gradient about 4 hours to reach the ship assuming a mean transport wind of $10 \mathrm{~ms}^{-1}$ in the MBL. Lower afternoon AOD values are observed due to the transport of a marine air mass by westerly winds associated with the developing sea breeze.

The continental air mass has more aerosols than the marine air mass and results in higher aerosol optical depths. Higher aerosol concentrations in the continental air mass also result in more scattering

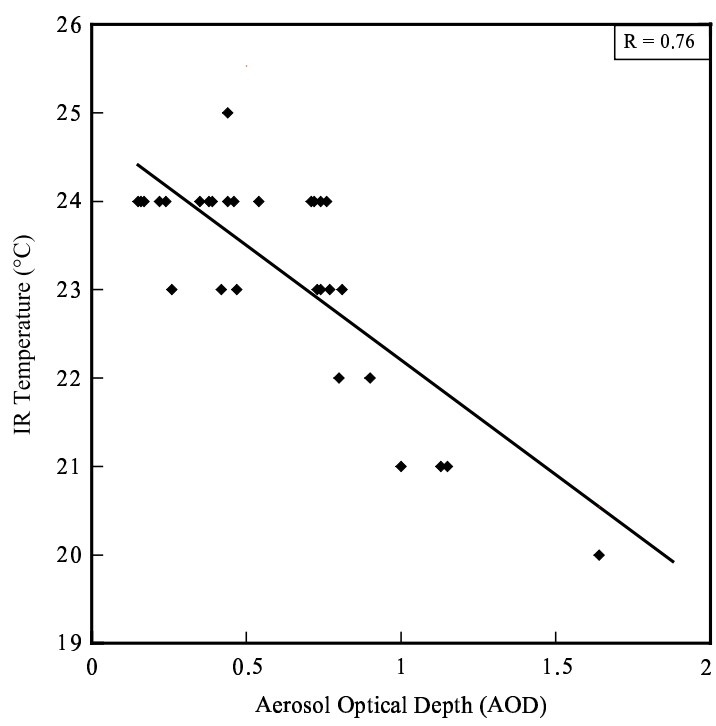

Figure 5. Measured aerosol optical depth and the corresponding observed satellite infrared temperature above the AOD measurement location. Infrared temperatures are shown to decrease with increasing aerosol optical depth due to scattering of the infrared signal. IR temperatures were only used when no clouds were present.

of satellite infrared (IR) signals. The correlation between AOD measured by R/V Sagar Kanya close to the west coast of India and the IR temperature measured by satellite above the location of the AOD measurement when no clouds are present is shown in figure 5. AOD measurements around 0.5 correspond to IR temperatures between 23 and $25^{\circ} \mathrm{C}$. As the AOD increases, the measured IR temperature is observed to decrease. High AOD measurements of 1 to 1.5 result in IR temperatures of 20 to $21^{\circ} \mathrm{C}$. The correlation between high AOD values and lower IR temperatures causes the pollution gradient to appear in satellite IR images as a strong gradient in IR temperatures over the Arabian Sea.

Remotely sensed data from the Meteosat-5 IR satellite is able to show the development and presence of the pollution gradient because the unpolluted marine air mass corresponds to the actual SSTs in infrared images and the polluted continental air mass to lower temperatures. Polluted air mass IR temperatures are lower than the marine air mass IR temperatures because of aerosol attenuation of the IR signal measuring the SST. The location of the pollution gradient is along the horizontal gradient of the higher and lower temperatures as observed by the IR sensor. Locations of the research vessels are denoted by "RB" (R/V Ron Brown) and "SK" (R/V Sagar Kanya) in the IR images in figure 6 .

No distinct gradient in measured IR temperatures over the Arabian Sea is observed at $2230 \mathrm{LT}$ on 5th March as shown in figure 6(a). At 2230 LT, 

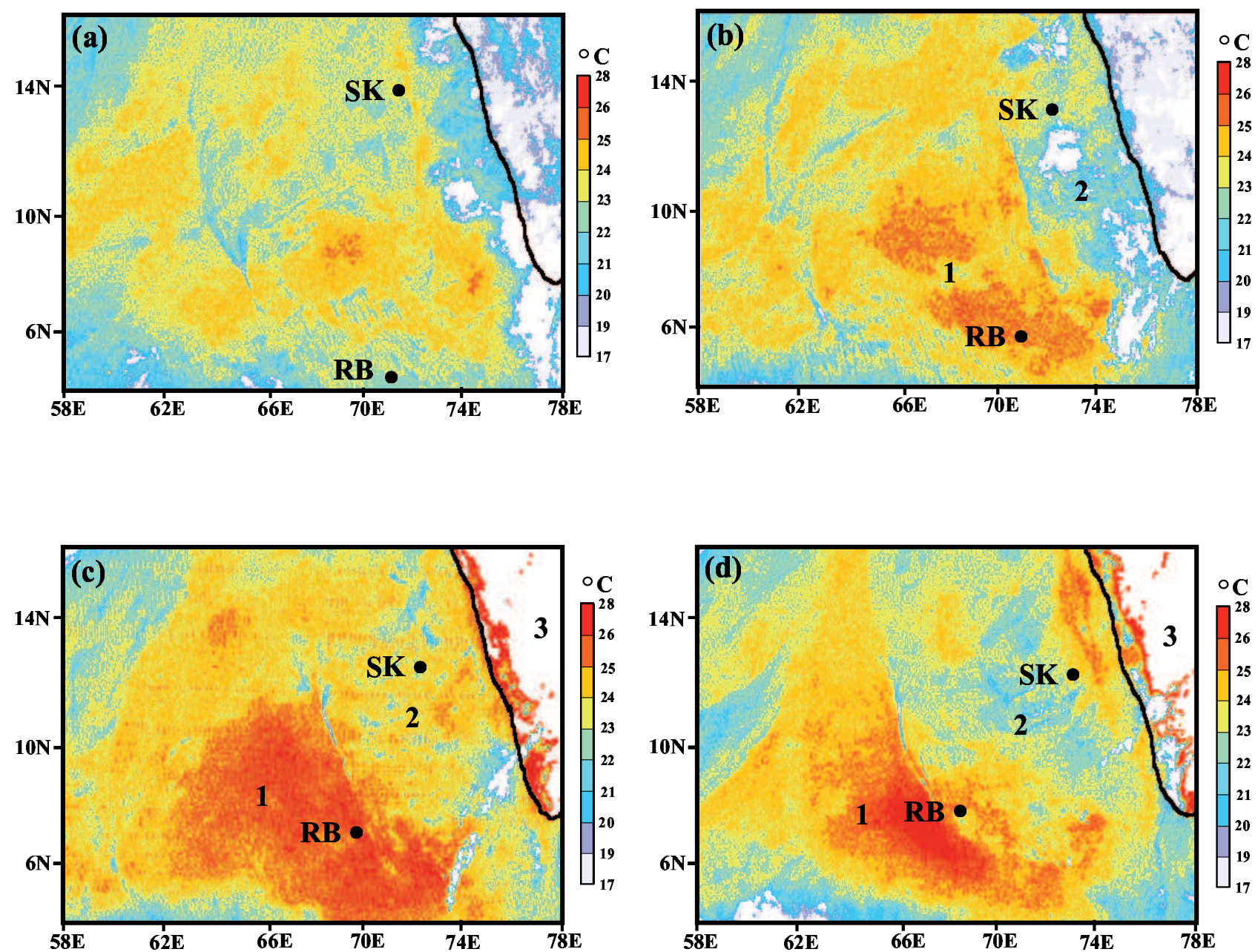

Figure 6. (a) Infrared satellite image at 2230 LT on 5th March with the location of Ron Brown denoted by "RB" and Sagar Kanya by "SK", (b) Infrared satellite image showing the location of a pollution gradient at 0430 LT on 6th March, (c) at $1030 \mathrm{LT}$ on 6th March, and, (d) at $1630 \mathrm{LT}$ on 6th March over the Arabian Sea.

the nighttime land breeze is just beginning to develop. There is no strong offshore flow to transport the polluted continental air mass over the Arabian Sea. The result is no distinct gradient in pollution concentrations over the Arabian Sea at this time.

A strong pollution gradient is apparent by 0430 LT on 6th March as shown in figure 6(b). The pollution gradient is located along the strong temperature gradient in the IR image at $72^{\circ} \mathrm{E}$ near the west coast of India. Formation of the pollution gradient at 0430 LT is believed to have been caused by the land breeze and strong NE winds (shown later). The region labeled "1" is the unpolluted marine air mass with significantly less aerosols than the continental air mass. Therefore, the IR signal is able to see the ocean surface without attenuation and records the warm sea surface temperature. The region labeled "2" is the aerosol rich continental air mass that shows up as cooler colors. This region appears cooler because the aerosols are scattering the infrared spectrum and result in a weaker signal. The location of the pollution gradient is along the gradient of polluted continental air mass (low IR temperatures) and the unpolluted marine air mass (high IR temperatures). The pollution gradient is oriented from north to south at a longitude of $72^{\circ} \mathrm{E} . \mathrm{R} / \mathrm{V}$ Ron Brown was located at $6.5^{\circ} \mathrm{N} 70.8^{\circ} \mathrm{E}$ in the unpolluted marine air mass at this time as shown in figure $6(\mathrm{~b})$.

By $1030 \mathrm{LT}$ on 6th March 1999, the location of the pollution gradient near the coast of India has moved to the west by about $200 \mathrm{~km}$ and is centered at a longitude of $71^{\circ} \mathrm{E}$ as shown in figure 6(c). The gradient is just east of $\mathrm{R} / \mathrm{V}$ Ron Brown which is located at $7.1^{\circ} \mathrm{N}, 70.2^{\circ} \mathrm{E}$. Again the clean marine air mass shows up as high temperatures in the IR image and is denoted as region "1". The aerosol rich continental air mass shows up as lower temperatures and is denoted by region "2". The gradient in infrared temperatures indicates the location of the pollution gradient. The 

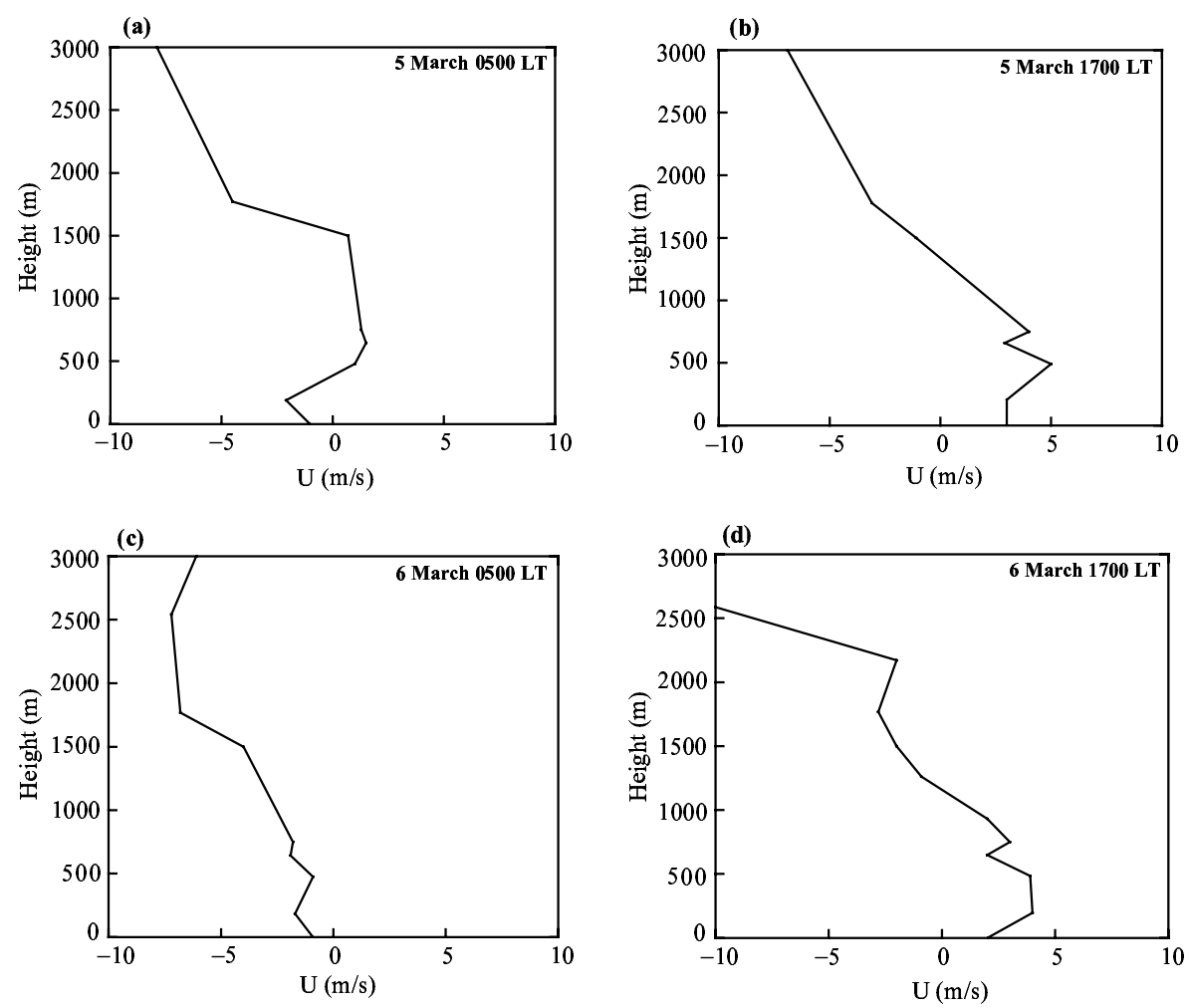

Figure 7. (a) Observed u-component of horizontal wind measured along the west coast of India at Mangalore at 0500 LT on 5th March 1999, (b) at 1700 LT on 5th March, (c) at 0500 LT on 6th March, and (d) at 1700 LT on 6th March, 1999.

region of high IR temperatures now appearing along the coast, denoted by region " 3 ", represents the advection of the marine air mass onshore by the developing sea breeze circulation.

At $1630 \mathrm{LT}$ on 6th March 1999, the gradient has become tilted with the northern region of the gradient around $66^{\circ} \mathrm{E}$ while the southern part of the gradient is still around $70^{\circ} \mathrm{E}$ as shown in figure 6(d). The gradient moved past R/V Ron Brown $\left(8.0^{\circ} \mathrm{N}, 69.3^{\circ} \mathrm{E}\right)$ at approximately $13: 00 \mathrm{LT}$ and one would expect to see the aerosol and gas concentration increase at this time (shown later). The clean marine air mass shows up as high IR temperatures and is labeled as region " 1 ". The aerosol rich continental air mass shows up as a region of lower temperatures and is labeled region " 2 ". The near shore region labeled " 3 " corresponds to the marine air mass being advected on shore by the strong daytime sea breeze. Formation of the sea breeze is discussed in a later section.

\section{Observations of sea and land breezes}

Sea and land breezes along the west coast of India appear to play a significant role in the formation and propagation of the pollution gradient. Investigating the variation of the diurnal coastal circulations is essential to fully understand the development of the pollution gradient.

Formation and eventual propagation of the pollution gradient appears to depend largely on the strength of the land and sea breezes along the west coast of India. The greatest change in the horizontal wind speed vector during land and sea breeze development will occur in the u-component of the wind because the Indian coastline is oriented from north to south. Observations from Mangalore, India showing the $\mathrm{u}$-component of the horizontal wind speed are shown in figure 7 . There are easterly (offshore) winds of 1 to $2 \mathrm{~ms}^{-1}$ from the surface up to $400 \mathrm{~m}$ at Mangalore on 5th March 0500 LT as shown in figure $7(\mathrm{a})$. Westerly (onshore) winds of 1 to $2 \mathrm{~ms}^{-1}$ are observed from 400 to $1500 \mathrm{~m}$ indicating the presence of possible return flow aloft. Above $1500 \mathrm{~m}$, the u-component shifts back to synoptic easterly (offshore) flow and remains so up to $3000 \mathrm{~m}$. This wind profile shows that a land breeze did develop at Mangalore.

By 1700 LT on 5th March, winds from the surface up to about $800 \mathrm{~m}$ are westerly (onshore) indicating the development of a sea breeze as shown in figure 7(b). Winds shift to synoptic easterly (offshore) flow and remain so up to $3000 \mathrm{~m}$ with a maximum value of $7 \mathrm{~ms}^{-1}$ thus showing a welldeveloped sea breeze circulation at 1700 LT. 
Easterly (offshore) winds develop again near the surface by 0500 LT on 6th March as shown in figure 7 (c). Winds are easterly from the surface up to $3000 \mathrm{~m}$ with values ranging from 1 to $7 \mathrm{~ms}^{-1}$. The presence of easterly winds throughout the lower troposphere and no defined land breeze circulation may have been influenced by a strong high pressure system (not shown) to the north of Mangalore with strong offshore winds.

A fully developed sea breeze was again observed at $1700 \mathrm{LT}$ on 6 th March at Mangalore with westerly winds of 2 to $4 \mathrm{~ms}^{-1}$ as shown in figure $7(\mathrm{~d})$. The onshore westerly winds were observed from the surface up to $1000 \mathrm{~m}$. Above $1000 \mathrm{~m}$, winds shift to easterly and remain so up to $3000 \mathrm{~m}$. A sea breeze appears to have developed despite the strong easterly winds caused by a high-pressure system to the north.

Observations from Mangalore show that strong onshore flow of about $5 \mathrm{~ms}^{-1}$ developed on 6th March 1999 as a result of the daytime sea breeze. During the night, the flow reverses and a land breeze is observed. The presence of synoptic features, such as a strong high pressure system to the north of Mangalore, can enhance the NE (offshore) flow during the night.

\section{Numerical simulation}

A numerical model is used to simulate the atmospheric flow that includes sea/land breezes and to test our hypothesis concerning the development and propagation of the pollution gradient over the Arabian Sea.

\subsection{Model description}

The mesoscale model used in this study is a threedimensional, non-hydrostatic version of the fifth generation of the PSU-NCAR Mesoscale Model (MM5) (Grell et al 1995). It is a primitive equation model that uses a non-dimensional $\sigma$-vertical coordinate system. The model uses surface layer similarity for the constant flux layer and MRF planetary boundary layer (PBL) parameterization scheme for the mixed layer (Hong et al 1996). The model also uses explicit equations for cloud water, rainwater, ice and water vapor. The Kain-Fritsch cumulus parameterization scheme is used for subgrid scale convection (Kain et al 1993). The ground temperature is calculated using a five-layer soil model scheme (Dudhia et al 1996).

In this study, we have used the operational analysis from NMC, produced by the National Center for Environmental Prediction (NCEP) and archived by the National Center for Atmospheric Research (NCAR) to prescribe initial conditions.

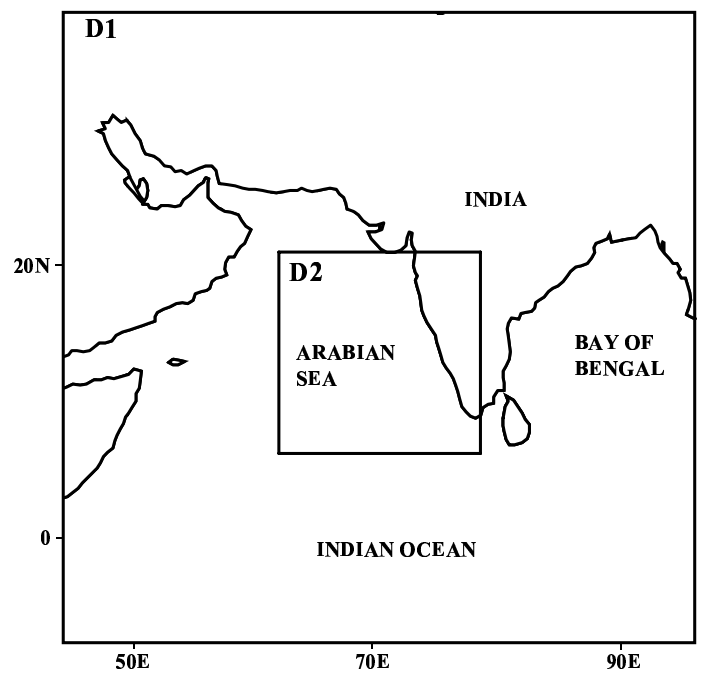

Figure 8. Map showing the outer coarse (30 km resolution) and inner fine (10 km resolution) domains used for the model simulation.

The resolution of the archived data is $2.5^{\circ} \times 2.5^{\circ}$ latitude-longitude with 15 standard pressure layers. The above data are interpolated onto the model grid to serve as initial values and to provide lateral boundary conditions for the model. Analysis corresponding to 0500 LT on 5th March 1999 was utilized. The model was integrated up to a period of 72 hours until 0500 LT on 8th March 1999. This time period was chosen because of the presence of the pollution gradient in infrared satellite imagery and availability of aerosol data from R/Vs Ron Brown and Sagar Kanya during the parallel track experiment.

A two-way nest is used for the model simulation. Locations of the inner and outer domains are shown in figure 8 . The grid spacing for the outer and inner domains are $30 \mathrm{~km}$ and $10 \mathrm{~km}$, respectively. The outer domain consists of $(186 \times 186)$ grid points while the inner domain has $(178 \times 178)$ grid points. Both domains have 36 vertical $\sigma$ levels between $1000 \mathrm{mb}$ and $100 \mathrm{mb}$ with 25 of the levels below $700 \mathrm{mb}$. The inner domain is arranged to include the mountains along India's west coast and a large portion of the Arabian Sea.

\subsection{Sea and land breeze}

A comparison between numerical simulations and observations is needed to insure that the model accurately simulated the atmospheric flow in general and the development of the land and sea breeze along the west coast of India in particular. The $\mathrm{u}$-component of the observed horizontal wind (solid line) at Mangalore, India and the model simulated u-component (dashed line) are shown in figure 9. The model simulates the observed presence of a weak land breeze at $0500 \mathrm{LT}$ on 5th March at 

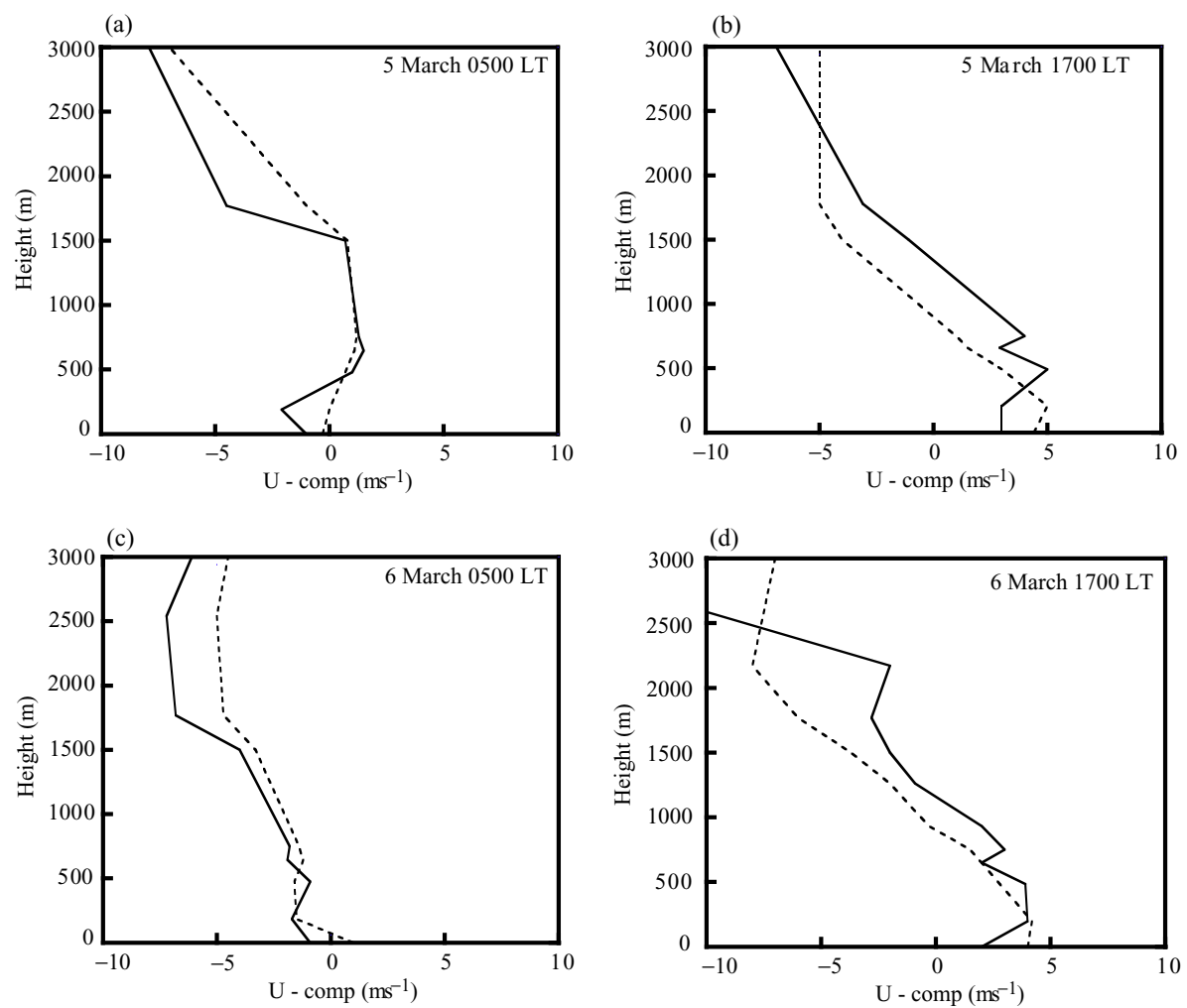

Figure 9. (a) Model simulated u-component (dashed line) of horizontal wind at Mangalore, India compared with observations (solid line) at $0500 \mathrm{LT}$ on 5th March, (b) at $1700 \mathrm{LT}$ on 5th March, (c) at $0500 \mathrm{Z}$ on 6 th March, and (d) at $1700 \mathrm{LT}$ on 6th March 1999.

Mangalore as shown in figure 9(a). The simulated u-component is approximately $0.5 \mathrm{~ms}^{-1}$ easterly at the surface and shifts to a westerly direction at $300 \mathrm{~m}$. Westerly winds are simulated above $300 \mathrm{~m}$ with values of 1 to $2 \mathrm{~ms}^{-1}$, which agree with observations. The simulated $\mathrm{u}$-component shifts back to easterly at $1500 \mathrm{~m}$ and remains so through $3000 \mathrm{~m}$. The model accurately simulated the shallow nighttime land breeze and the weak return flow aloft occurring at Mangalore.

By $1700 \mathrm{LT}$ on 5th March, the daytime sea breeze circulation has developed as shown in figure 9(b). The model simulated the shift in the $\mathrm{u}$-component direction at the surface to westerly winds from the nighttime easterly winds 12 hours earlier. Westerly winds are simulated up to $1000 \mathrm{~m}$ that then shift to easterly. The model simulated the development of the sea breeze to an altitude of $800 \mathrm{~m}$.

At $0500 \mathrm{LT}$ on 6th March, the observed $\mathrm{u}$-component is easterly from the surface to $3000 \mathrm{~m}$ as shown in figure $9(\mathrm{c})$. The model simulates the easterly winds up to $3000 \mathrm{~m}$ except for a weak westerly flow of about $0.75 \mathrm{~ms}^{-1}$ at the surface. However, the simulated u-component quickly shifts to easterly at $100 \mathrm{~m}$.

Both observations and the model simulated ucomponent show the development of the sea breeze by $1700 \mathrm{LT}$ on 6 th March as shown in figure 9(d). The simulated u-component is westerly at the surface and shifts to easterly at $1000 \mathrm{~m}$ in agreement with the observations. Again, the model simulated the development of the daytime sea breeze at Mangalore.

\section{$5.3 \mathrm{MBL}$ heights}

A comparison of MBL heights is provided to show that the model could simulate the growth of the MBL with distance from the west coast of India. Model simulated MBL heights and corresponding observations of the MBL heights from R/Vs Ron Brown and Sagar Kanya are shown in figure 10. Comparisons between MBL heights observed (solid line) from soundings taken from $\mathrm{R} / \mathrm{V}$ Ron Brown, around $800 \mathrm{~km}$ off the coast of India, and model simulated MBL heights (dashed line) are shown in figure 10(a). The model simulated MBL heights agree in general with the observed heights with the maximum difference being approximately $200 \mathrm{~m}$. The average MBL height is around $900 \mathrm{~m}$ at this distance $(800 \mathrm{~km})$ from the Indian coastline.

Comparisons between MBL heights observed (solid line) from soundings taken from R/V Sagar Kanya, located at about $140 \mathrm{~km}$ off the coast of India, and the model simulated MBL heights 

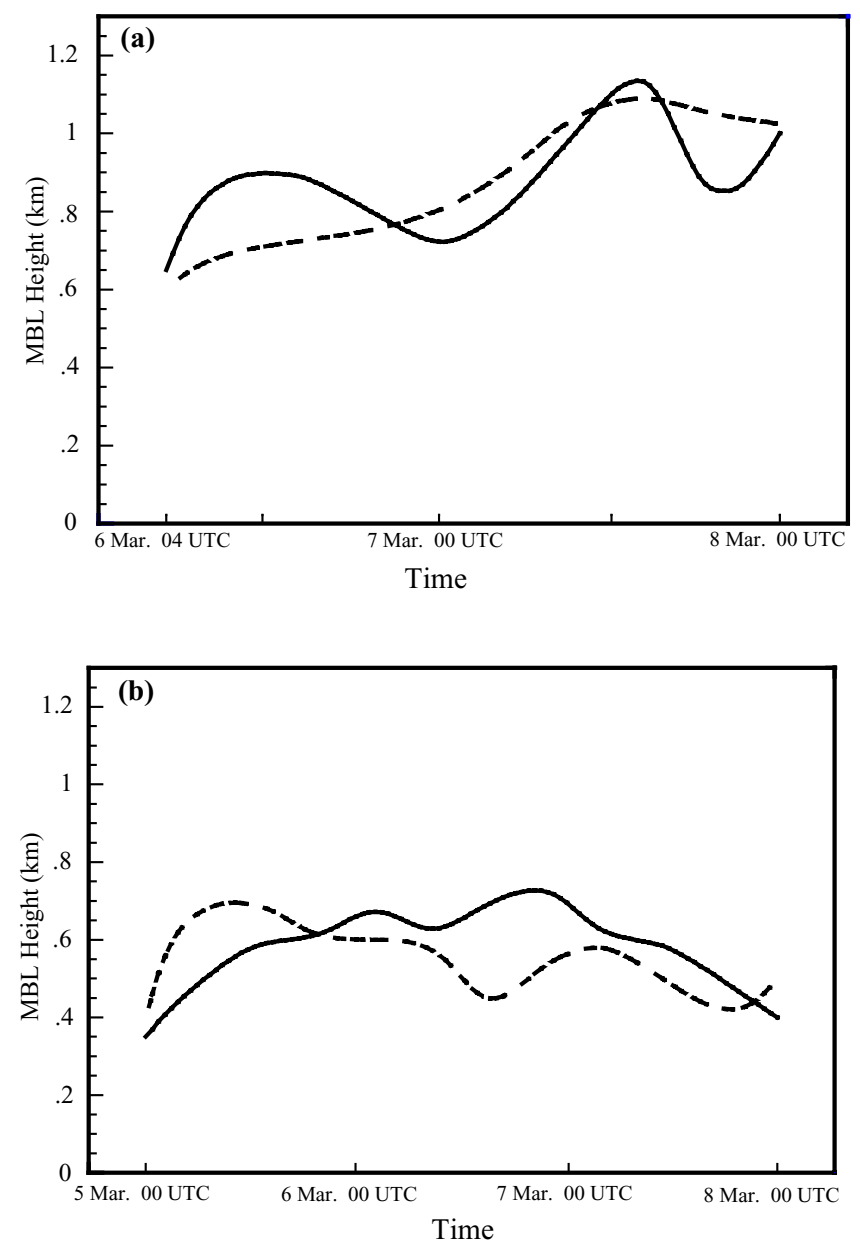

Figure 10. (a) Model simulated marine boundary layer heights (dashed line) compared with observations (solid line) from R/V Ron Brown and (b) R/V Sagar Kanya.

(dashed line) at this location are shown in figure 10(b). The observed MBL heights are lower than the heights recorded by $\mathrm{R} / \mathrm{V}$ Ron Brown because R/V Sagar Kanya was much closer to the Indian coastline. The model simulates the lower MBL heights closer to the coast reasonably well. Model-simulated MBL heights are within $\pm 100 \mathrm{~m}$ of the observed MBL heights except for a few locations. The model has been able to simulate the growth of the MBL with distance from the Indian coast and the simulations are reasonable.

\subsection{Pollution gradient simulation}

The location of the pollution gradient is best found by plotting simulated low-level convergence. Model simulated convergence at an altitude of $10 \mathrm{~m}$ for the inner domain is shown in figure 11 . Corresponding locations of the pollution gradients derived from the IR satellite imagery shown previously in figure 6 are overlaid as solid lines with the model simulated convergence for comparison.
At $2300 \mathrm{LT}$ on 5th March 1999, the maximum simulated convergence associated with the pollution gradient over the Arabian Sea is $6 \times 10^{-5} \mathrm{~S}^{-1}$ as shown in figure 11(a). The land breeze is strengthening at this time, so the development and propagation of a pollution gradient as a result of the offshore flow is soon expected to occur.

By 0500 LT 6th March 1999, the land breeze is at its maximum strength and a large area of convergence is simulated over the Arabian Sea about $300 \mathrm{~km}$ from the west coast of India as shown in figure 11(b). This area of simulated convergence represents the location of the developing pollution gradient. The maximum convergence within the pollution gradient is approximately $8 \times 10^{-5} \mathrm{~s}^{-1}$. Location of the simulated convergence is close to the observed location of the pollution gradient from the IR satellite imagery.

At 1100 LT 6th March 1999, the simulated convergence associated with the gradient has reached a maximum of $10 \times 10^{-5} \mathrm{~s}^{-1}$ and the location of the pollution gradient is clearly discernable in figure 11(c). The pollution gradient extends for about $800 \mathrm{~km}$ over the Arabian Sea. Since 0500 LT, the gradient has moved $80 \mathrm{~km}$ to the west. Again, the location of the simulated convergence closely corresponds to the observed location of the pollution gradient. Convergence is now seen along the west coast of India because of the on-shore flow associated with the sea breeze.

The strength and coverage of simulated convergence diminishes by 1700 LT 6th March 1999 as shown in figure $11(\mathrm{~d})$. The maximum convergence has decreased to $7 \times 10^{-5} \mathrm{~s}^{-1}$ and is only found in two small regions within the larger area of weaker convergence. Weakening of the convergence has occurred because the sea breeze circulation is now at a maximum for the day and has turned the winds from NE to SE. The wind shift has resulted in more convergence along the west coast of India and less over the Arabian Sea. Strong convergence extending along the west coast of India shows the impact of the sea breeze circulation. Large regions of convergence with values of around $24 \times 10^{-5} \mathrm{~s}^{-1}$ occur along the west coast of India.

Looking at a cross section of the low level convergence associated with the pollution gradient will show the depth of the pollution gradient and its propagation. Location of the convergence cross sections is indicated in figure 12 (a) by point "A" $\left(7^{\circ} \mathrm{N}, 68^{\circ} \mathrm{E}\right)$ over the Arabian Sea to location "B" $\left(13^{\circ} \mathrm{N}, 76^{\circ} \mathrm{E}\right)$ along the west coast of India. The orientation of the cross section is arranged so that it runs through the location of pollution gradient as shown earlier in figure 6 . The depth of the cross section is only $4 \mathrm{~km}$ since we are primarily concerned with the dynamics of the pollution gradient in the lower troposphere. 

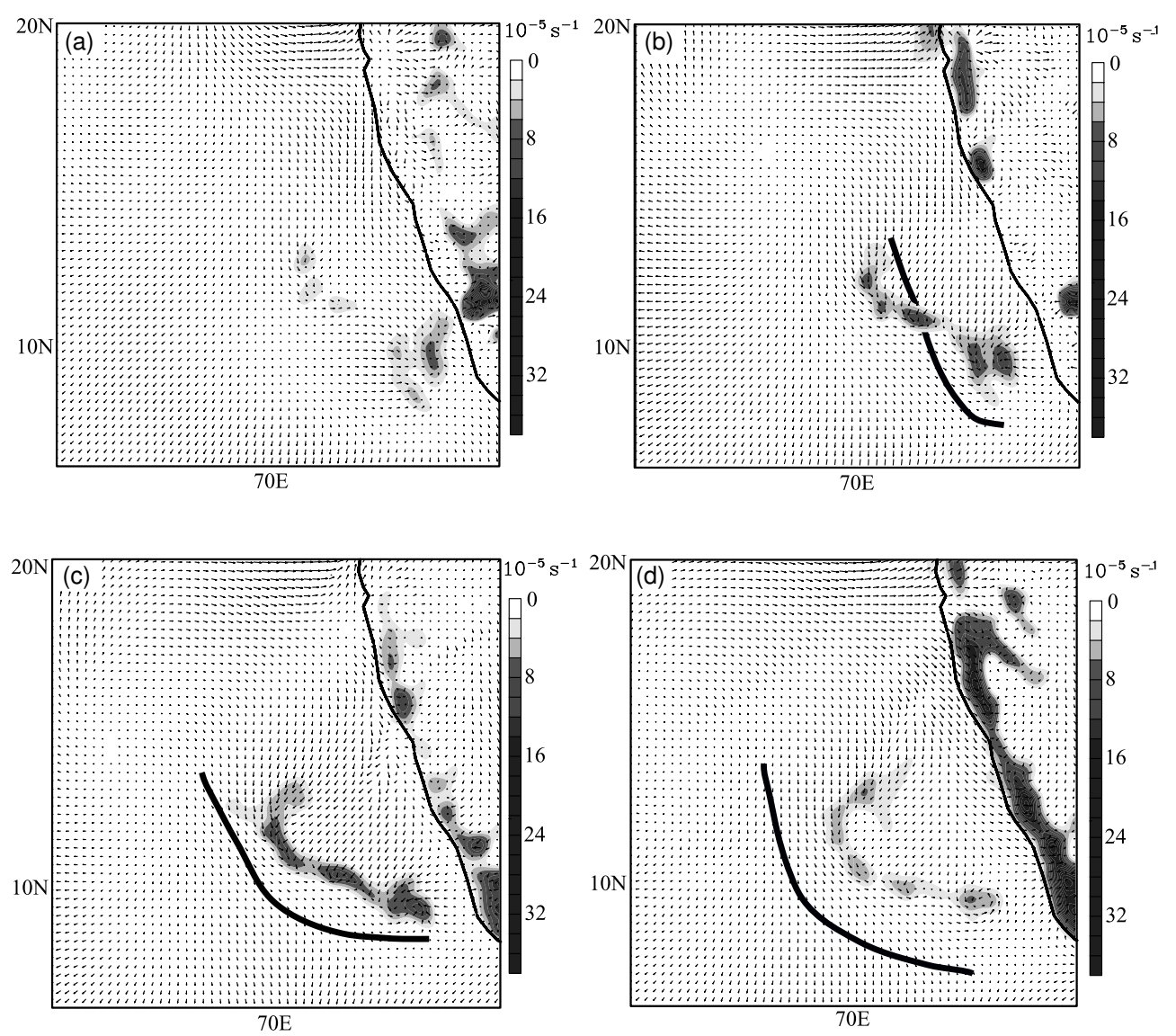

Figure 11. (a) Model simulation convergence at $10 \mathrm{~m}$ height at $2300 \mathrm{LT}$ on 5 th March 1999, (b) at $0500 \mathrm{LT}$ on 6 th March, (c) at $1100 \mathrm{LT}$ on 6th March, and (d) at $1700 \mathrm{LT}$ on 6th March. Solid line represents the corresponding observed location of the pollution gradient derived from infrared satellite imagery.

At $0500 \mathrm{LT}$ on March 6th, an area of convergence is simulated at approximately $350 \mathrm{~km}$ off the west coast of India as seen in figure 12(b). The region of simulated convergence corresponds to the location of the pollution gradient shown earlier in figure $6(\mathrm{~b})$. The maximum simulated convergence at this time is around $10 \times 10^{-5} \mathrm{~s}^{-1}$. Positive vertical velocities of about $0.16 \mathrm{~ms}^{-1}$ are simulated and extend up to $3 \mathrm{~km}$. Depth of the pollution gradient is simulated to be around $700 \mathrm{~m}$.

Maximum simulated convergence has increased to $18 \times 10^{-5} \mathrm{~s}^{-1}$ by $1100 \mathrm{LT}$ on 6th March 1999 as shown in figure 12 (c). The gradient has propagated towards the west and is now $420 \mathrm{~km}$ from the west coast of India. Depth of the simulated convergence has grown to $900 \mathrm{~m}$ by this time. A maximum positive vertical velocity of $0.18 \mathrm{~ms}^{-1}$ results from the convergence.

By 1700 LT on 6th March 1999, the offshore flow has weakened and results in less convergence over the Arabian Sea as shown in figure 12(d). The gradient is now $500 \mathrm{~km}$ from the west coast of India. The maximum convergence has decreased to $8 \times 10^{-5} \mathrm{~s}^{-1}$ and the depth is again around
$700 \mathrm{~m}$. The maximum positive vertical velocity has decreased to around $0.06 \mathrm{~ms}^{-1}$.

Positive vertical motion is one of the features associated with the propagation of the pollution gradient as shown in the cross sections of figure 12 . Simulated vertical velocity at a height of $1000 \mathrm{~m}$ at $1100 \mathrm{LT}$ on 6th March 1999 is shown in figure 13. The simulated vertical velocity is present over a distance of about $600 \mathrm{~km}$ over the Arabian Sea. Maximum simulated vertical velocity at $1000 \mathrm{~m}$ is around $0.08 \mathrm{~ms}^{-1}$ while the majority of vertical velocity is around 0.04 to $0.05 \mathrm{~ms}^{-1}$. Location of the simulated vertical motion corresponds well with the location of the pollution gradient as shown earlier in figure 6(c).

Another simulation was run using the same model physics except for no subgrid scale convective parameterization for the inner domain. Using no convective parameterization will give a more realistic representation of the clouds forming as a result of the low level convergence associated with the propagation of the pollution gradient. The total simulated cloud-mixing ratio at $1100 \mathrm{LT}$ on 6th March 1999 at a height of $900 \mathrm{~m}$ over the 
(a)

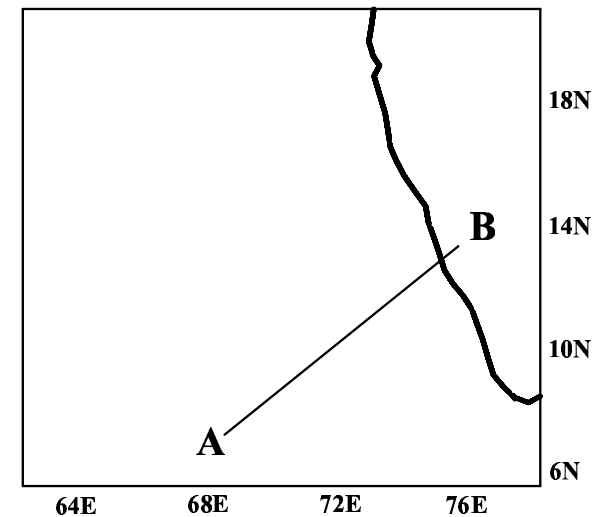

(c)

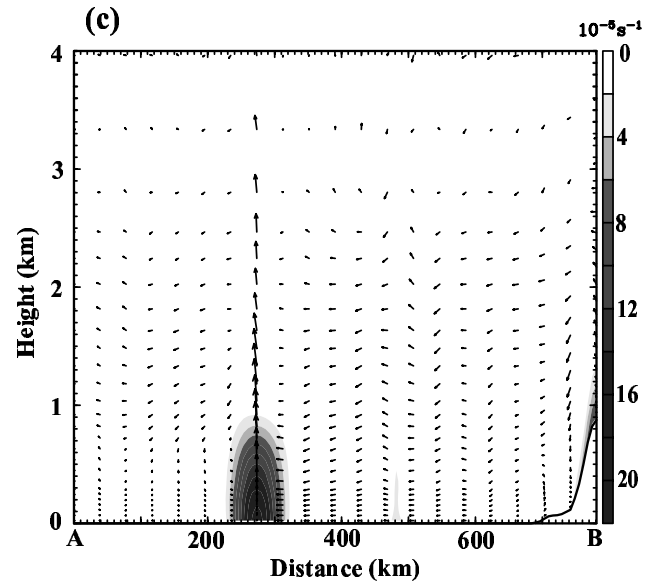

(b)

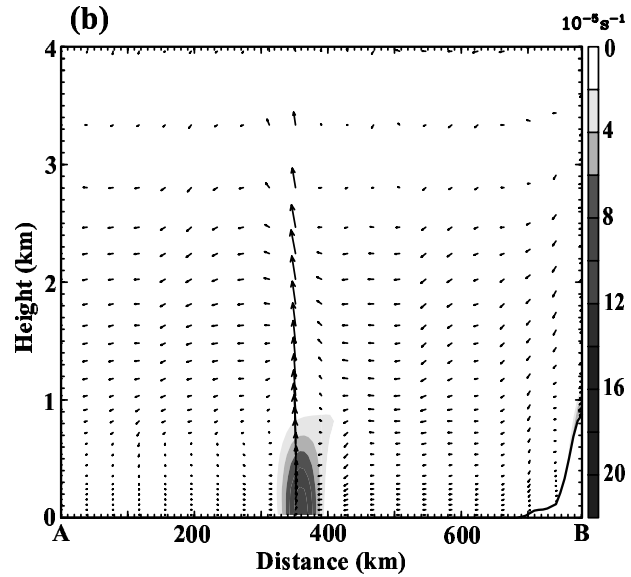

(d)

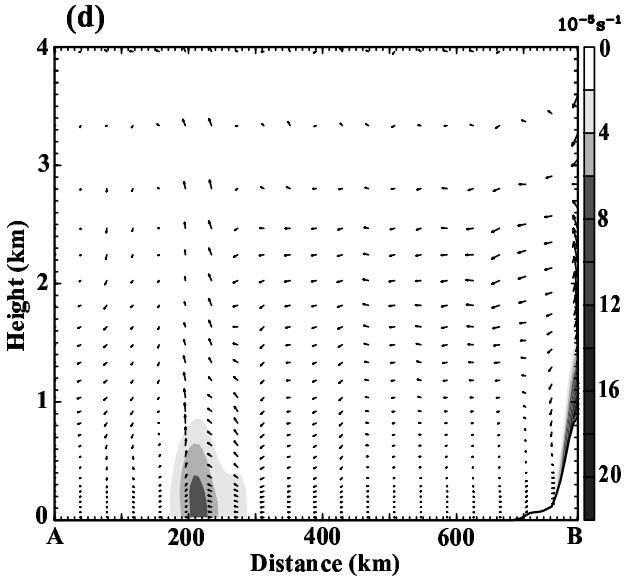

Figure 12. (a) Map showing the location of the cross section, (b) cross section of model simulated convergence across the pollution gradient over the Arabian Sea at 0500 LT on 6th March, (c) same as 13(b), but at 1100 LT on 6th March, and (d) same as 13(b), but at $1700 \mathrm{LT}$ on 6th March 1999.

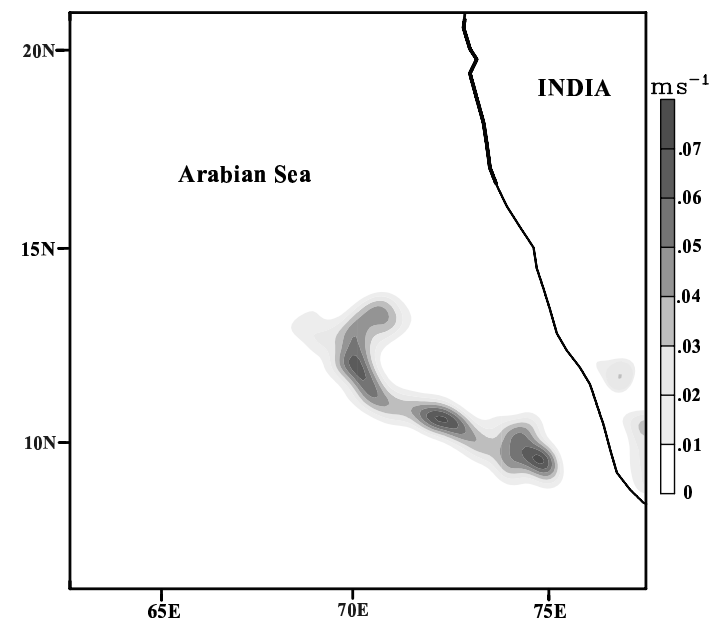

Figure 13. Model simulated vertical velocity at a height of $900 \mathrm{~m}$ at $1100 \mathrm{LT}$ on 6th March over the Arabian Sea. The vertical velocity results from the low level convergence associated with the pollution gradient propagation.

Arabian Sea is shown in figure 14. Low stratocumulus clouds are simulated over the Arabian Sea because of the positive vertical motion (shown in figure 13) associated with the pollution gradient. The simulated clouds are located around $300 \mathrm{~km}$ off the west coast of India and stretch from $71^{\circ} \mathrm{E}$ to $67^{\circ} \mathrm{E}$. The length of the clouds extends from $8^{\circ} \mathrm{N}$ to $13^{\circ} \mathrm{N}$ with the majority of the cloud cover along $13^{\circ} \mathrm{N}$. Maximum simulated cloud-mixing ratio is $0.096 \mathrm{~g} \mathrm{~kg}^{-1}$, but the majority of the cloud-mixing ratio values are between 0.020 and $0.040 \mathrm{~g} \mathrm{~kg}^{-1}$. Simulated cloud liquid water agrees with a narrow cloud band (not shown) observed by visible satellite.

\subsection{Trajectory simulation}

One method of testing our hypothesis that the formation of the convergence zone and pollution gradient is related to the sea and land breeze circulation is to plot model simulated trajectories. Ideally, a trajectory should show a parcel move offshore by the land breeze and interact with an area of offshore convergence. A simulated trajectory starting at a height of 200 meters along the west coast of India (labeled A) at 0500 LT on 5th 


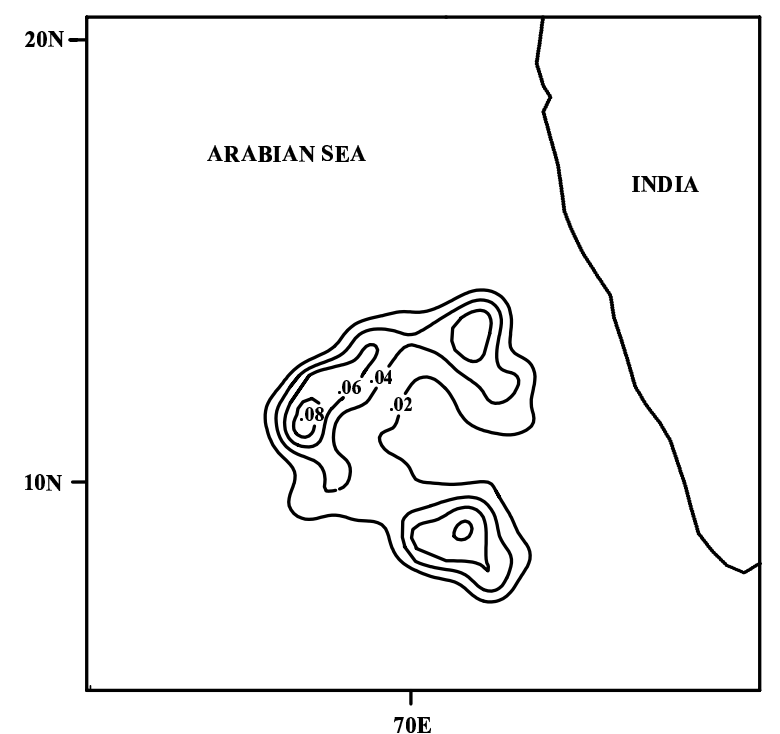

Figure 14. Model simulated total cloud-mixing ratio in $\mathrm{g} \mathrm{kg}^{-1}$ at $1100 \mathrm{LT}$ on 6th March 1999 at a height of $900 \mathrm{~km}$ over the Arabian Sea resulting from positive vertical velocity associated with the pollution gradient.

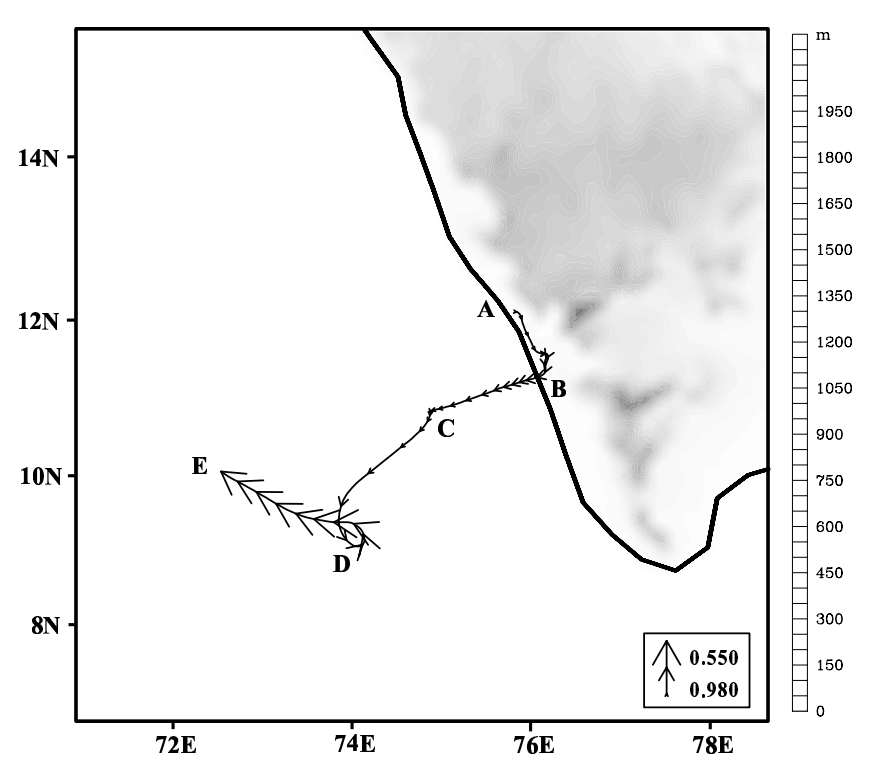

Figure 15. Model simulated trajectory from 0500 LT on 5th March 1999 (labeled A) to 0500 LT on 8th March 1999 (labeled E) released at a height of $200 \mathrm{~m}$ along the west coast of India. Movement of the trajectory is influenced by the sea breeze (B), the offshore convergence zone associated with the pollution gradient (C), and an offshore circulation (D). Terrain heights are shown over India.

March 1999 is shown in figure 15. Terrain heights over India are also shown in figure 15 . The parcel is shown to move along the west coast of India after release and eventually begins moving inland as a result of the developing sea breeze on the afternoon of 5th March 1999. The parcel is raised to a height of around $1300 \mathrm{~m}$ by the inland circulation of the sea breeze. By 1500 LT of 5th March 1999 (labeled
B), the parcel is moving offshore as a result of the return circulation of the sea breeze. Strong northeast winds aloft begin transporting the parcel offshore at around 2300 LT on 5th March 1999. As the parcel moves offshore it decreases in altitude and is at a height of $200 \mathrm{~m}$ by $1100 \mathrm{LT}$ on 6th March. At 1700 LT on 6th March 1999 (labeled C), the parcel interacts with an area of convergence as shown earlier in figure 11. Interaction with the convergence zone results in the parcel slowing down in speed and changing the direction of its movement. The parcel is lifted to a height of about $600 \mathrm{~m}$ by the positive vertical motion (shown earlier in figure 13) associated with the convergence zone. Interaction between the parcel trajectory and the offshore circulation shown earlier in figure 11 at $0900 \mathrm{LT}$ on 7th March 1999 (labeled D) lifts the parcel higher to a height of about $4000 \mathrm{~m}$. The parcel remains at a height of $4000 \mathrm{~m}$ until the end of the simulated trajectory (labeled E) at $0500 \mathrm{LT}$ on 8th March 1999. Movement of the simulated trajectory thus shows the influence of the sea and land breezes along the west coast of India in conjunction with the offshore convergence zone associated with the pollution gradient.

\section{Conclusions}

A hypothesis for the formation and propagation of a pollution gradient over the Arabian Sea is proposed. The pollution gradient is defined as a boundary between the unpolluted marine air mass over the Arabian Sea and the air mass high in aerosol and anthropogenic gas concentrations originating from the Indian sub- continent.

Sea and land breeze circulations are shown to occur along the west coast of India. Strong onshore winds were observed during the day while the flow shifts to offshore during the night. The development of the pollution gradient occurs when the easterly winds advect a polluted air mass offshore creating a sharp gradient in aerosol and anthropogenic gas concentrations. Propagation of the pollution gradient over the Arabian Sea occurs with offshore winds during the night transporting the anthropogenic aerosols and gases.

Observations near the west coast of India during INDOEX (1999) revealed several peaks in aerosol number concentration caused by the passage of pollution gradients. Peaks in carbon monoxide concentration were shown to result from the passage of the pollution gradients. The timing of the occurrence of concentration peaks correlated well with the timing of the pollution gradient passage observed from infrared satellite images.

A mesoscale model was employed to verify the hypothesis of the formation and propagation of 
the pollution gradient. The numerical model simulated the formation of the pollution gradient and its propagation over the Arabian Sea. The gradient appears to develop as a result of the diurnal coastal circulations. As the sea breeze weakened, the pollution gradient was pushed out to sea by the large-scale easterly winds. Simulated convergence agreed well with the observations. The depth of the aerosol gradient extended to a height of $800 \mathrm{~m}$ above the surface. Maximum vertical velocities of about $0.22 \mathrm{~ms}^{-1}$ were simulated from the low level convergence associated with the pollution gradient. Stratocumulus clouds at $900 \mathrm{~m}$ were shown to develop as a result of the vertical velocity caused by the pollution gradient.

A model simulated trajectory showed the movement of a parcel to be influenced by the sea and land breeze circulations and the offshore convergence zone associated with the pollution gradient. The trajectory was released along the west coast of India and pushed offshore by return flow of the sea breeze and strong northeast winds aloft. Speed of the parcel diminished as it approached a region of offshore convergence associated with the pollution gradient. The parcel slowing down ahead of the convergence zone explains how the transport of a continental air mass results in polluted air building up on one side of the convergence zone resulting in the observed pollution gradient.

Transport of aerosols and anthropogenic gases is shown to occur in the marine boundary layer through the development and propagation of the pollution gradient. This represents one mechanism of regional transport of pollution from the Indian subcontinent over the Arabian Sea and the Indian Ocean during the northeast monsoon.

\section{Acknowledgements}

This research was supported by the Atmospheric Sciences Division of the National Science Foundation under Grant ATM-0080088. Computer resources were provided by the North Carolina Supercomputing Center, RTP and the Scientific Computing Division (SCD) of NCAR and the State Climate Office of North Carolina. We thank Dr. A Jayaraman, Physical Research Laboratory, Ahmedabad, India for the R/V Sagar Kanya aerosol data.

\section{References}

Désalmand F, Szantai A, Picon L and Desbois M 2003 Systematic observation of westward propagating cloud bands over the Arabian Sea during Indian Ocean Experiment (INDOEX) from Meteosat-5 data; J. Geophys. Res. 108(D18), 8004.

Dudhia J 1996 A multi-layer soil temperature model for MM5. Preprints, The Sixth PSU/NCAR Mesoscale Model Users' Workshop, Boulder, CO, Natl. Ctr. Atmos. Res.

Grell G, Dudhia J and Stuaffer D 1995 A description of the Fifth-Generation Penn Sate/NCAR Mesoscale Model (MM5), NCAR Technical Note NCAR/TN - 398 +STR, p. 122 .

Hong S-Y and Pan H-L 1996 Nonlocal boundary layer vertical diffusion in a medium-range forecast model; Mon. Wea. Rev. 124 2322-2339.

Jayaraman A, Satheesh S K, Mitra A P and Ramanathan V 2001 Latitude gradient in aerosol properties across the Inter Tropical Convergence Zone: Results from the joint Indo-US study onboard Sagar Kanya; Current Science 80 128-137.

Johnson J, Gammon R, Larsen J, Bates T, Oltmans S and Farmer J 1990 Ozone in the marine boundary layer over the Pacific and Indian Oceans: Latitudinal gradients and diurnal cycles; J. Geophys. Res. 95 11847-11856.

Kain J S and Fritsch J M 1993 Convective parameterization for mesoscale models: The Kain-Fritsch scheme. The Representation of cumulus in numerical models (eds) K A Emanuel and D J Raymond, Meteorological Monographs. Amer. Meteor. Soc. 165-170.

Lal S, Naja M and Jayaraman A 1998 Ozone in the marine boundary Layer over the tropical Indian Ocean; J. Geophys. Res. 103 18,907-18,917.

Moorthy K K and Saha A 2000 Aerosol study during INDOEX: observation of enhanced aerosol acitivity over the Mid Arabian Sea during the northern winter; J. Atmos. Solar-Terr. Phys. 62 65-72.

Quinn P K and Coffman D J 1998 Local closure during the First Aerosol Characterization Experiment (ACE 1): Aerosol mass concentration and scattering and backscattering coefficients; J. Geophys. Res. 103(D13), $16,575-16,596$.

Ramanathan V, Crutzen P, Coakley J et al 1995 Indian Ocean Experiment (INDOEX) White Paper, C-4 Pulbication \# 143; Scripps Inst. Ocean., UCSD, 1995.

Rhoads K, Kelley P, Dickerson R, Carsey T, Farmer M, Savoie D and Prospero J 1997 Composition of the troposphere over the Indian Ocean during the monsoonal transition; J. Geophys. Res. 102 18,981-18,995.

Satheesh S K, Krishan Moorthy K and Krishan Murthy B V 1998 Spatial gradients in the aerosol characteristics over tha Aravian Sea and Indian Ocean; J. Geophys. Res. 103 26,183-26,192.

Stehr J W, Ball W P, Dickerson R R, Doddridge B G, Piety C A and Johnson J E 2002 Latitudinal gradients in $\mathrm{O}_{3}$ and $\mathrm{CO}$ during INDOEX 1999; J. Geophys. Res. 107 (D19) 8015. 